\title{
Correction to: High-dose opioid utilization and mortality among individuals initiating hemodialysis
}

Matthew Daubresse ${ }^{1,2}$, G. Caleb Alexander ${ }^{1,2,3}$, Deidra C. Crews ${ }^{4}$, Dorry L. Segev ${ }^{1,5}$, Krista L. Lentine ${ }^{6}$ and Mara A. McAdams-DeMarco ${ }^{1,2,5^{*}}$

\section{Correction to: BMC Nephrology 22, 65 (2021) https://doi.org/10.1186/s12882-021-02266-5}

Following publication of the original article [1], the authors identified an error in the author name of Krista L. Lentine.

The incorrect author name is: Krista Lentine

The correct author name is: Krista L. Lentine

The author group has been updated above. The original article has been corrected.

\footnotetext{
Author details

${ }^{1}$ Department of Epidemiology, Johns Hopkins Bloomberg School of Public Health, 615 N. Wolfe Street W6033, Baltimore, MD 21205, USA. ${ }^{2}$ Center for Drug Safety and Effectiveness, Johns Hopkins University, Baltimore, MD, USA. ${ }^{3}$ Division of General Internal Medicine, Department of Medicine, Johns Hopkins Medicine, Baltimore, MD, USA. ${ }^{4}$ Division of Nephrology, Department of Medicine, Johns Hopkins University School of Medicine, Baltimore, MD, USA. ${ }^{5}$ Division of Surgery, Department of Medicine, Johns Hopkins University School of Medicine, Baltimore, MD, USA. ${ }^{6}$ Division of Nephrology, Department of Internal Medicine, Saint Louis University School of Medicine, Saint Louis, MO, USA.
}

Published online: 15 April 2021

\section{Reference}

1. Daubresse, et al. High-dose opioid utilization and mortality among individuals initiating hemodialysis. BMC Nephrology. 2021;22:65 https://doi. org/10.1186/s12882-021-02266-5.

The original article can be found online at https://doi.org/10.1186/s12882021-02266-5

* Correspondence: mara@jhu.edu

'Department of Epidemiology, Johns Hopkins Bloomberg School of Public Health, 615 N. Wolfe Street W6033, Baltimore, MD 21205, USA

${ }^{2}$ Center for Drug Safety and Effectiveness, Johns Hopkins University, Baltimore, MD, USA

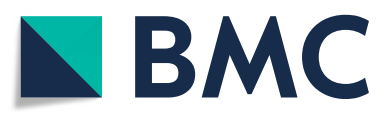

() The Author(s). 2021 Open Access This article is licensed under a Creative Commons Attribution 4.0 International License, which permits use, sharing, adaptation, distribution and reproduction in any medium or format, as long as you give appropriate credit to the original author(s) and the source, provide a link to the Creative Commons licence, and indicate if changes were made. The images or other third party material in this article are included in the article's Creative Commons licence, unless indicated otherwise in a credit line to the material. If material is not included in the article's Creative Commons licence and your intended use is not permitted by statutory regulation or exceeds the permitted use, you will need to obtain permission directly from the copyright holder. To view a copy of this licence, visit http://creativecommons.org/licenses/by/4.0/ The Creative Commons Public Domain Dedication waiver (http://creativecommons.org/publicdomain/zero/1.0/) applies to the data made available in this article, unless otherwise stated in a credit line to the data. 